\title{
Public Memory, Commemoration and Transitional Justice: Reconfiguring the Past in Public Space
}

Duncan Light and Craig Young

In: Lavinia Stan and Nadya Nedelsky (eds) (2015) Post-Communist Transitional Justice: Lessons from 25 Years of Experience, Cambridge University Press, Cambridge, pp , 233-251

\section{INTRODUCTION}

Transitional justice is usually addressed through institutional processes such as lustration, restitution, prosecution and "truth commissions", around which a comprehensive academic literature has developed. However, this chapter explores a relatively neglected symbolic dimension of transitional justice ${ }^{1}$, namely practices of memorialization and commemoration that are represented, played out and contested in urban space. There is widespread acknowledgment within the transitional justice literature that memorialization - in the form of monuments, statues and museums - has a key role to play in healing the wounds of the communist past. Such memorials "represent a critical terrain where the past is confronted and conflict can be addressed"2. Memorialization is a means of giving recognition to those who suffered hardship, repression, exile or death under Communist regimes. The practice makes a visible statement about what (and who) a political order considers worthy of remembrance and is a means of reaching large numbers of people over an extended period of time.

In this chapter we focus on the various ways in which transitional justice for the victims of Communist regimes is expressed in the highly complex entanglement of urban cultural 
landscapes, public memory, and commemorative sites and practices. We contend that attempts to shape public memory through practices of commemoration and memorialization are important (if neglected) aspects of transitional justice, that have much to tell us about how post-communist societies choose to remember - and forget - the period of Communist Party rule. Following a review of the relationships between public memory and urban space we begin by examining efforts to erase the commemorative landscape produced by communist regimes. We then look at the variety of initiatives (by diverse elites and publics) to commemorate the victims of Communist regimes, with particular reference to monuments, memorials and museums. We also highlight the importance of both domestic and international tourism to these sites of memory as central to the way in which they 'work'.

\section{PUBLIC MEMORY, COMMEMORATION AND URBAN SPACE}

Public memory can be defined as "a body of beliefs and ideas about the past that help a public or society understand both its past, present, and by implication, its future" ${ }^{\text {"3 }}$. It is a society's collective understanding of the past, but also the ways that this past is represented in the present. ${ }^{4}$ Since memory is integral to the formation of identities ${ }^{5}$, collective (or public) memory has long been important in the construction of collective identities. In particular, nation-states construct and promote a particular understanding of the past within nationbuilding projects that are intended to foster social cohesion and a sense of allegiance to a particular 'imagined community'. ${ }^{6}$ The formation of such a collective memory involves choices about what a society wishes to remember. Nevertheless, while states may play a leading role in the construction of collective memory they do not enjoy a monopoly over this process. Instead various elites and publics both within and without the state (each of which 
may be fractured by competing and contesting agendas) participate in the process ${ }^{7}$ so that the formation of public memory is a fluid process of negotiation. ${ }^{8}$ Public memory "emerges from the intersection of official and vernacular cultural expressions"9 and, for this reason, it is best regarded as an activity or process, rather than an outcome. ${ }^{10}$

An important aspect of public memory which is central to our argument in this chapter is that it is a process which is worked out in the public arena. This is achieved through various practices of remembrance and commemoration intended to reify public memory by turning it into visual spectacle. In particular, human geographers argue that urban space - or landscape - is essential to the 'working' of public memory. ${ }^{11}$ All political orders seek to create an 'official public landscape" ${ }^{12}$ which is intended as a rhetorical statement of specific political values. Remembrance and commemoration are central aspects of such landscapes: indeed, Edensor ${ }^{13}$ has coined the term 'memoryscape' for those parts of the urban landscape that are given over to collective remembrance. The urban environment can be the setting for a range of temporary (if cyclical) commemorative practices including ceremonies, parades, festivals and rituals. However, most forms of commemoration are permanent and include a range of statues, monuments, memorials and other public buildings, along with commemorative names attached to streets, buildings and other urban landmarks. Such commemorative practices concretise 'official' conceptions of public memory, rendering it seemingly immutable in the public arena. They can, however, also be sites for the expression of opposition to, and contestation of, this official public memory.

Since public memory is produced in a particular political context it is vulnerable to any process of political change. In particular, all shifts of political power "generate a reconfiguration of the "known past"". ${ }^{14}$ This issue is of particular relevance in post- 
communist societies which have sought to build political identities based on an emphatic rejection of communism (a strategy which generally enjoyed widespread popular support). In this context such societies faced the need for a new, appropriate and 'usable' past to replace now discredited communist-era constructions of the collective past. The most readily available model was that of the period before communist rule. ${ }^{15}$ Thus, throughout EastCentral Europe there has been a focus on the pre-communist past as the model for a postcommunist future. As Katherine Verdery ${ }^{16}$ has argued, this is about effectively excising the communist period from the historical time line (and, initially, denying that it ever happened) and returning to the period before the Second World War; it suggests that history is able to resume the authentic trajectory it would have taken, had it not been for the 'aberration' of four decades of communist party rule. Clearly in post-communist contexts, the past is something that is fluid and flexible, with different state and non-state groups competing to establish a new historical narrative.

Similarly, public memory is also in a state of reformation. ${ }^{17}$ Within the political transformation from totalitarianism to democracy, post-communist societies face new choices about what (and who) they want to remember, and how (and where) this remembrance will be enacted. At the same time as seeking to forget communism, the new societies will want to remember the repression and violence of the former regime, and to honour the victims of state persecution. There may also be a desire to remember the events that brought about the collapse of Communist regimes (even if, in some cases, these events did not in themselves bring about a clear break with those regimes). Moreover, given that the urban landscape is central to the expression of public memory these debates will, in some way, be worked out in urban space. In particular there will be a significant remaking of the commemorative landscape. People and events that were honoured by the previous regime will be de- 
commemorated and their memorials removed from the public arena. New acts of commemoration will subsequently follow in a way that accords with the political values and public memory of the new regime.

In this way, practices of commemoration and memorialization within the urban landscape can be important (if often overlooked) elements of transitional justice projects in post-communist states. Indeed, memorialization and collective remembrance are fundamental processes in societies recovering from traumatic pasts. ${ }^{18}$ Barsalou and Baxter ${ }^{19}$ argue that memorialization has a number of roles in such projects: it offers symbolic reparations to the victims of violence; it can promote reconciliation; it can encourage engagement with education programmes about the recent past; and it creates specific sites that can be the focus both of individual mourning and official ceremonies of remembrance. Of particular relevance to our argument in this chapter, is that memorialization makes a highly visible statement in the public arena about a post-communist society's commitment to a new set of political values. In fact, of all the forms of transitional justice, memorialisation is probably the most visible and has the potential to have an impact on the everyday lives of the greatest number of people. Yet, to date, there has been only sporadic attention in the transitional justice literature to the role of memorialization projects within the urban landscape. This reflects a broader context in which political scientists have paid relatively little attention to the role of monuments and memorials as political symbols. ${ }^{20}$ In the following sections we explore changing practices of memorialization in post-communist East-Central Europe, focussing firstly on the removal of the commemorative landscapes created by communist regimes, and secondly, on the efforts to create new memorial sites and landscapes within transitional justice projects. 


\section{ERASING THE COMMEMORATIVE LANDSCAPE OF COMMUNISM}

When Communist Party regimes came to power in the late 1940s they immediately set about remaking public memory. This was principally achieved through a comprehensive rewriting of history and total control over the education system. It also included a comprehensive remaking of the urban landscape to decommemorate the historical narrative associated with the now-discredited former regime. Since communist regimes attached especial importance to the transformative power of public space for creating a new socialist consciousness ${ }^{21}$ the public arena effectively became an instrument of state propaganda. An entirely new commemorative landscape was produced which was saturated with a variety of symbols (including statues, memorials, monuments, plaques, murals, banners, and slogans) ${ }^{22}$ that were intended to shape the ways that people thought about their individual and collective pasts.

As communist regimes in East-Central Europe started to collapse in 1989 their official commemorative landscapes swiftly became the targets of protest, resulting in the familiar process of 'landscape cleansing'. ${ }^{23}$ This activity was initiated by the populace during the euphoria that accompanied the collapse of Communist Party rule and continued by the new post-communist administrations. This process satisfied the demand to see evidence of political change. ${ }^{24}$ Czepczyński ${ }^{25}$ identifies a number of strategies for landscape cleansing: removal, renaming, rededication and reuse. The most visible strategy is removal, where monuments placed by the communist states were directly expunged from the urban arena. By far the most iconic images of the collapse of communist regimes were the removal of statues of Soviet figures such as Lenin. These events required considerable organisation and resources, and so were usually orchestrated by the state. ${ }^{26}$ They provided a dramatic and 
highly visible proclamation that political order was changing. However, in most cases the eradication of communist statuary was both less spectacular and less immediate, with most removals taking place quietly during the early years of the post-communist period. ${ }^{27}$ Only in a few instances were communist monuments destroyed in situ: the dynamiting of Georgi Dimitrov's mausoleum in Sofia in 1999 was the best example. ${ }^{28}$

However, in most instances communist monuments and statues were not destroyed but instead they were simply moved to new locations. For example, in Hungary, the Budapest city authority made the decision in 1991 to remove over 40 communist-era statues and monuments and relocate them in an open-air museum on the edge of the city - named 'Statuepark' - which opened to visitors in 1993. This strategy allowed the monuments to be retained both as historical artefacts and as reminders of a traumatic past but in a way that emasculated their symbolic power within the urban landscape. ${ }^{29}$ In other cases the removal of communist statues was vigorously contested. The best example is the 'Bronze Soldier' in Tallinn, Estonia which commemorated Soviet soldiers who had fallen in the liberation of the city at the end of the Second World War. As an obviously Soviet symbol its presence in the city centre was unwelcome for the post-communist Estonian government which, in 2007, made the decision to move the memorial to a military cemetery on the edge of the city. This provoked violent protest by Estonia's Russian minority who interpreted the removal of the statue as an attack on their heritage and identity. ${ }^{30}$

A less dramatic strategy was the renaming of streets, buildings and other urban landmarks to de-commemorate events and personalities from communist-era historiography. This practice has been termed "toponymic cleansing". ${ }^{31}$ Such renaming is "an act of political propaganda with immense proclamative value and public resonance" ${ }^{32}$ : it makes an immediate statement 
that public memory is changing, and is relatively quick and simple to implement. Renaming was intended to decommemorate the communist past and also to 'place' a new narrative of national history and memory into public space. However, renaming urban streets and buildings was relatively limited in scale and was most prominent in the central areas of towns and cities. Since many toponyms allocated during the communist era had no ideological connotations they did not need to be renamed. So, for example, in Bucharest only $6.6 \%$ of the city's streets were renamed after $1989^{33}$ and in other post-communist cities the proportion was lower.

Strategies of rededication and reuse were applied mostly to museums. Communist regimes attached considerable importance to museums ${ }^{34}$ as a means of socialist propaganda so that hundreds of new museums were established in communist East-Central Europe. Most countries had at least one museum dedicated entirely to the history and activities of that country's Communist Party. These were complemented by a network of regional and local museums, all of which interpreted local history through the lens of Marxism-Leninism. With the fall of Communism, the museums dedicated to Party history were swiftly closed. Some reopened as different museums (for example, in Bucharest the former 'History Museum of the Communist Party, of the Revolutionary and Democratic Movement of Romania' reopened in 1990 as the 'Museum of the Romanian Peasant ${ }^{35}$ ) while in other cases, the buildings were put to entirely new uses. As the formerly communist states were gripped by 'collective amnesia' about the recent past almost all museums simply closed any galleries which dealt with the communist period: the displays remained in place but in locked rooms with no public access. Bădica ${ }^{36}$ describes this as the "black hole paradigm" where the historical narrative presented in museums simply ended in 1945. 
Overall, then, the efforts to neutralise the commemorative symbols of communism (and the public memory that they represented) was a crude first step in achieving redress for the abuses and hardship of the communist era. However, the process of landscape cleansing was always partial. It was applied most thoroughly to the central parts of cities (particularly capitals) and to a lesser extent (and sometimes hardly at all) in more peripheral districts. Its target was the most visible and iconic symbols of the communist regime, while smaller or more inconspicuous symbols were often ignored or overlooked. Removing or reconfiguring the commemorative landscape of communism effectively cleared space in the urban arena for an entirely new set of commemorative practices that were specifically intended to remember the victims and abuses of communism. These are discussed in the following section

\section{COMMEMORATING THE VICTIMS OF, AND RESISTANCE TO, COMMUNIST REGIMES}

Within strategies to redefine public memory there have been two broad strands to the remaking of commemorative landscapes. First, in the effort to (re)establish a 'normal' past post-socialist societies have attempted to correct the distortions of communist-era historiography. In addition to de-commemorating key figures from the communist version of history there has been a focus on reinstating and re-commemorating those people (such as politicians and monarchs) who were excised from public memory by communist historians. This, in turn, resulted in new practices of memorialisation in the public arena and, once the official public landscape had been de-communised, it could be repopulated with new monuments, statues, memorials and toponyms. The most straightforward way to do this was by returning streets to their pre-communist commemorative names. For example, in central 
Bucharest 14 streets commemorating pre-communist politicians that had been renamed by the communist regime returned to their former names, as did 4 streets which commemorated the Romanian monarchy. ${ }^{37}$ Over time, new statues and monuments were commissioned to commemorate those figures who had been disavowed during the communist period. For example a statue of Tomáš Masaryk was erected in Prague in 2000, and a statue of King Carol I (based on an earlier statue destroyed by the communist regime) was unveiled in Bucharest in 2010. Such practices represent a symbolic correction of a form of historical injustice, although they are not usually considered as part of transitional justice projects.

Second, post-communist societies faced the challenge of how to remember the communist period and how to commemorate its victims. Although in many countries there was an initial desire to forget the communist past completely, at a later stage there was general agreement that the abuses of communism should be memorialised. The construction of memorials, monuments and museums is a means of acknowledging the abuses of the communist era; giving recognition to the victims; and promoting a sense of social cohesion and belonging that is rooted in a traumatic recent past. ${ }^{38} \mathrm{~A}$ range of actors, both within and outside the state participate in such memorialisation. In some countries governments have been very active in promoting remembrance of the abuses of Communist Party regimes ${ }^{39}$ as a form of transitional justice that compliments other legal and institutional measures. States can also use practices of memorialization to affirm and legitimate (to both domestic and international audiences) their commitment to political values that are the antithesis of communism. ${ }^{40}$ Civil society groups and non-governmental organisations have also been active in memorialising the communist past, particularly in those countries where former communist officials have remained in power and have been more unwilling to condemn the communist era. ${ }^{41}$ In addition, ordinary individuals can also be involved in the process of remembrance through 
creating and placing their own, informal memorials in the urban landscape. The commemorative landscape is therefore characterised by a bricolage of memorial forms, dedicated to different subjects and groups, in a wide range of locations, and with a wide range of sponsors. Here, we focus on two broad categories of memorialization: first, monuments and memorials, and second, museums (with associated practices of tourism)

\section{Monuments and Memorials}

For states engaged in enacting transitional justice the erection of monuments and statues in the public arena has provided one means of recognition of the injustices of the Communist past. As a result there are many examples of such commemoration, although it is by no means a thorough, consistent and comprehensive practice. Indeed, what is perhaps surprising is the relative paucity of such memorials combined with the controversy that they sometimes generate. Representing the condemnation of the Communist past and its injustices through memorialisation is not, therefore a straightforward process.

The memorials that have been erected differ widely in terms of their form, the subject that they commemorate, and the sponsoring organisation behind them. Some memorials commemorate the actions and death of a specific individual. While they focus on the sacrifice of the individual they implicitly draw attention to the broader injustices of the regimes responsible. Examples here include the monument in Prague to Jan Palach, the student who committed suicide in January 1969 in protest against the Soviet repression of the "Prague Spring". A bronze cross is now embedded into the spot outside the national museum where he died. Palach is also commemorated through the naming of a square in Prague, several other 
memorials throughout Europe, and even the naming (by a Czech astronomer) of an asteroid after him. Other memorials are dedicated to groups of individuals who died in specific sites. A key example is the memorials to those killed trying to cross the Berlin Wall. The White Crosses memorial features seven crosses inscribed with the names of thirteen people who were killed in this way. First erected by a private group in 1971 in West Berlin it has always been associated with key symbolic parts of the urban landscape, initially being located near the Reichstag and now beside the offices of the new unified German government. Deaths associated with the Berlin Wall are also commemorated generically at the Gedenkstätte Berliner Mauer (Berlin Wall Memorial).

Some memorials acknowledge deaths associated with specific events or more broadly with specific aspects of totalitarian oppression. These include a series of memorials to victims of the KGB in Tartu, Vilnius, Riga and Potsdam, and memorials to the Katyn massacre. In Moldova a stone cross at Răzeni commemorates the ten victims of the Soviet-led massacre of 1941, while in Chişinău there is a Memorial to the Victims of Stalinist Repression. A plaque in a square just off Rustavelli Avenue in Tbilisi, Georgia, commemorates those killed by Soviet forces during protests in 1956 (ironically protests partly motivated by the denouncement of Stalin). In Gdańsk (Poland) the Monument to the Fallen Shipyard Workers of 1970 memorial was unusually erected during the Communist period itself (in 1980). Other memorial sites are aimed more broadly at remembering the national experience of Communism. For example, the Memorial to the Victims of Communism in Prague, erected in 2002, seeks to shape the collective memory of those who died under Czechoslovak Communism. Supported by the local authority and the Confederation of Political Prisoners (KPV) it seeks to commemorate those who suffered politically and personally, detailing the numbers shot or who died in prison, were arrested or exiled. A bronze plaque reads: "The memorial to the victims of 
communism is dedicated to all victims not only those who were jailed or executed but also those whose lives were ruined by totalitarian despotism". This memorial has attracted some criticism for its gendered nature (no female figures are represented) and for its aesthetic qualities, raising the issue of the public reception of such forms of commemoration.

Finally, some monuments commemorate collective suffering under Communism and are intended to denounce the period as a whole. Such monuments sometimes prove to be controversial. The Gloria Victis Memorial is located on the outskirts of Budapest, Hungary, and seeks to honor "one hundred million casualties of universal communism". This memorial is the first to attempt to commemorate all the victims of Communist repression and was erected in 2006 (the fiftieth anniversary of the 1956 Hungarian Revolution). This memorial is more complex than those commemorating individuals or specific groups, and incorporates local, national and international representations of the victimization of citizens. It includes a world map of victims; memorials to the Ukrainian minority in Hungary; tablets commemorating the Molotov-Ribbentrop Pact, Jewish and Roma victims of Communism, and the Katyn massacre; and the text of Resolution 1481 (2006) of the Council of Europe entitled The Necessity of International Condemnation of the Crimes Committed by Totalitarian Communist Regimes. Clearly such a memorialization process becomes significantly more complex when trying to represent the suffering of all the victims of Communism, compared to the memory of an individual.

In addition to memorialising the abuses of communist regimes, various monuments commemorate the events that brought about the overthrow of Communist Party regimes in 1989. Pearce ${ }^{42}$ suggests that some post-socialist states have encountered problems in trying to establish official commemorative practices around the events of 1989 (such as which key 
dates or events should form the basis of state-sponsored commemoration). In some cases, the official narrative of events is strongly contested. For example, in 2005 Romania erected a Memorial of Rebirth in Bucharest which was intended to symbolise the struggle against the Ceausescu regime and to commemorate those who died in the violent 'revolution' of 1989. It is the official site of remembrance and the setting for state-led performances and rituals which attempt to shape post-communist visions of Romania's past and future. However, the monument itself has been roundly criticised on aesthetic and architectural grounds. Moreover the site holds little resonance for many Romanians who interpret the events of December 1989 more as a coup d'état than a genuine popular revolution. Consequently the Memorial of Rebirth has failed to become the focus of popular allegiance and its role in shaping public memory among Romanians is unclear.

This overview of the use of monuments, plaques, statues and memorials is not intended to be exhaustive but instead seeks to demonstrate the range of types of memorialisation practices which attempt to place transitional justice into the public arena. There is not space here to discuss in detail the design and symbolism of each of these sites (although this is an important subject for further research). Moreover, we know relatively little about the public reaction to and reception of - such commemorative landscapes. However the examples above give hints of how even what might appear to be a straightforward process - condemning Communism and commemorating its victims in public space - in fact can be contested and subject to debate. The example of the Memorial of Rebirth illustrates that while political elites may seek to shape transitional justice projects and the remembrance of the victims of communism, they may not always succeed. Instead, projects to shape commemoration and public memory can sometimes be contested and challenged by the populace. The public reception of sites and practices of memorialisation remains a neglected aspect of transitional justice. 


\section{Museums and Tourism}

To fully appreciate the role of museums within transitional justice projects it is important to recognise that museums are not simply collections of objects put on public display for the education and entertainment of visitors. Instead, museums have always had a broader ideological purpose. They are a form of public culture through which political elites tell a society about itself and where it has come from. In particular, those museums that are sponsored by the state have an important role in 'telling the national story'. They are institutions that are intended to be visited by the citizenry and which have a clearly articulated educational mission. They aim to communicate a particular understanding of the past and in this context they play a significant role in the making (and remaking) of public memory. More broadly, as a means of 'staging' the nation ${ }^{43}$ museums contribute to the formation of collective identities and their importance within nation-building projects is widely acknowledged. ${ }^{44}$ As the earlier discussion noted, communist regimes were fully aware of the educative and propagandist role of museums in communicating their political agenda (and the associated narrative of national history) to a broad public.

In a post-communist context, museums are important 'vehicles of memory" ${ }^{45}$ within projects to memorialize the communist past. In particular, museums can tell the story of the oppression, human rights abuses and suffering inflicted by Communist Party regimes. This, obviously, is a story that has not been formally told before (since it was not something that communist regimes were likely to draw attention to). Moreover, museums can interpret the communist period from the perspective of the people who lived through it. This is a bottomup narrative of history that focuses on everyday lives of ordinary people, rather than the macro-political agenda of the communist state and its leading political party. Memorial 
museums also interpret communist rule for future generations who did not experience it themselves in order to help them understand the experiences that shaped their parents' and grandparents' generation. Museums can also be locations for ceremonies and rituals intended to commemorate the victims of communist rule. Overall, memorial museums that are established as part of transitional justice projects are institutions intended to encourage remembrance, reflection and civic engagement. ${ }^{46}$ But they are not just about the communist past: museums can also be used to make an unambiguous statement about a state's postcommunist political identity and aspirations. In this context they are sites for "performances of democracy, not static representations of national identity". ${ }^{47}$ The use of museums in this way is, of course, as equally ideological as anything seen during the communist period, but now for entirely different ends.

What is important - but frequently overlooked - is the role of tourism in this process. Memorial museums are intended to be visited (and as such they function as visitor 'attractions' even if their subject matter is far from attractive). Some of the visitors to memorial museums will be children and young people, studying the communist period as part of their educational curriculum. However, most people will be visiting during their leisure time. Furthermore many of these people will be tourists (conventionally defined as people staying away from their home area for at least 24 hours) who can be both domestic (citizens of a country travelling within that country) and international (visitors from other countries). Although political scientists may be inclined to dismiss tourism as rather trivial and with little to offer in understanding politics, there is growing interest within the discipline of tourism studies in the ways that tourism can contribute to broader political projects and objectives. ${ }^{48}$ For example, visiting historic buildings and monuments is a means of 'connecting' with the broader community of the nation ${ }^{49}$ and as such tourism can be identified as one form of banal 
nationalism. ${ }^{50}$ Tourism can also be used to project political identities to an external audience. For example, a number of recent studies have explored how the Central and Eastern European countries have used their state-sponsored tourism promotional materials to project a distinctly post-communist political identity to the wider world. ${ }^{51}$

In the context of transitional justice projects, tourists can be encouraged to visit particular places (such as museums) in order to purposefully communicate to them a message about the communist past and the post-communist future. Moreover, many of these people will be heritage tourists who are interested in, and receptive to, learning during their leisure time ${ }^{52}$. For domestic tourists, the visit to a memorial museum performs the same role as other monuments and memorials: it is a reminder of the traumas of the recent past, a recognition of the victims of that past, and a warning to future generations. At the same time it is an affirmation of the rejection of communism and a commitment to broader 'European' values. However, international tourists are an equally important (and sometimes numerically dominant) audience (and for this reason most memorial museums make extensive use of displays and interpretation in the English language, and often in a range of other European languages). Most international visitors will have no direct experience of living under Communist Party rule (and often little background knowledge or understanding of communism). Therefore museums are a way of telling such visitors the story of "what we lived through' and 'the events that shaped us'. It is also a way of affirming and legitimating a commitment to the same political and economic agendas that have underpinned European integration since the Second World War.

There are an increasing number of museums in the Central and Eastern European countries that explicitly address the communist era. Most countries have a national museum (usually a 
monumental building located in the capital city) and these increasingly include a gallery dedicated to the recent past (although such galleries are usually fairly neutral historical accounts of the communist period). There are also museums specifically dedicated to interpreting the nature of life in a communist state. Some (such as the Museum of Communism in Prague or the DDR Museum in Berlin) have been set up by private entrepreneurs in order to cater for the interest of Western visitors, rather than being intended to contribute to transitional justice projects. However, there are many other museums have been established with the direct or indirect support of the state authorities, specifically to remember the abuses and victims of communist rule. Perhaps the best examples are Estonia's Museum of Occupations (which opened in 2003 in a purpose-built structure), the Museum of the Occupation of Latvia (opened 1993) and Lithuania's Museum of Genocide Victims (established 1992 in the former headquarters of the Soviet Security service). Each is located in the respective capital city. All are run by foundations although with state support. The motto of Latvia's museum - "Remembering, Commemorating, Reminding"53 clearly indicates the place of the museum within the broader project of achieving transitional justice. The displays of these museums focus on the nature of totalitarian rule; the impact on politics, economy and domestic life; the nature of domestic repression and human rights abuses; the activities of resistance groups; and the struggle for, and achievement of, independence in the early 1990s. All receive large numbers of foreign tourists and are also included in the itineraries of visiting politicians and dignitaries.

Other museums have been opened in buildings that were formerly prisons or were associated in other ways with the repressive apparatus of communist regimes. The conversion of such buildings into memorial museums is a form of symbolic 're-inscription' that is intended to give them a new use for memorialising the practices that they formerly hosted. The best 
example is the Memorial to the Victims of Communism and to the Resistance in Sighet, Romania. This opened in 1998 in a building that had formerly been used as a prison and in which the majority of the pre-War Romanian political, military, social and academic elite had been imprisoned after the communist regime took power. The museum was developed by the Civic Academy Foundation (a non-governmental organisation) with the financial support of the Council of Europe. It hosts summer schools for young Romanians and publishes regular volumes of academic study about the communist era. ${ }^{54}$ Its significance as a site of public remembrance of the human rights abuses of the communist regime was recognised by the Romanian government which declared it a site of national interest in legislation of 1997.

Another celebrated example is the former headquarters of the East German security service (the 'Stasi') in Berlin which opened as memorial and research centre in November 1990. As with other examples the site was managed by a non-governmental civil rights organisation, although with the support of the German government. The complex includes a museum with displays about the history and activities of the Stasi. Elsewhere in Berlin a former Stasi prison and interrogation centre also opened in 1994 as a museum and memorial (the BerlinHohenschönhausen Memorial). It is run by a private foundation with government support and aims to encourage "a critical awareness of the methods and consequences of political persecution and suppression in the communist dictatorship". ${ }^{55}$ Another example is Budapest's House of Terror, again established by a public foundation with government backing. It is housed in the former headquarters of the Hungarian security police (ÁVH). This site is intended as a memorial to those Hungarians who were interrogated and tortured by the communist regime, an interpretation of life in communist Hungary, and an account of the struggle against the communist regime which ended in $1989 .{ }^{56}$ Significantly, it is also one of Budapest's most popular tourist 'attractions'. Elsewhere throughout post-communist Central 
and Eastern Europe there are numerous smaller prisons and interrogation centres that have been turned into museums, intended for both domestic and international visitors.

Memorial museums are not without their critics. Although tourism is one of the principle means through which memorial sites are encountered there has long been a tendency to dismiss the practices of visitors to such places as trivial or insignificant. At best, tourists who visit places associated with trauma or tragedy are regarded as passive and unquestioning consumers who are incapable of fully appreciating the significance of the story presented to them and, at worst, as shallow thrill-seekers who are motivated by "a morbid and senseless curiosity" ${ }^{57}$ However, recent research within the disciplines of tourism studies and anthropology has demonstrated that the behaviour of visitors to memorial places is far more purposeful and significant than is often appreciated, and that visitors can be engaged in highly meaningful acts of remembrance and engagement with the subject matter they encounter. ${ }^{58}$ Other authors $^{59}$ accept that visits to memorial museums may be associated with short term learning, understanding and changed attitudes but they question the longer-term impacts of such visits in bringing about deeper learning and a broader engagement with the issues of transitional justice. Overall, then, the 'consumption' of memorial museums by their visitors is clearly a subject which merits much fuller research.

\section{CONCLUSIONS}

Issues of memorialisation and the reformulation of public memory are often considered to be 'soft' aspects of transitional justice and consequently they have not received as much academic attention as the 'hard' politics of truth commissions, lustration or restitution. 
However we argue that the issue of shaping public memory through commemorative practices and landscapes is an integral element of transitional justice projects which merits much fuller investigation. In concluding we highlight the importance of considering the cultural politics of transitional justice and we identify the lessons of accepting such a perspective.

One overall lesson that emerges from considering public memory and its expression in the urban landscape is that transitional justice is not only played out in the spaces of courtrooms, legislatures and administrations. It is also worked out in public squares, memorial landscapes and museum. Indeed, we need to recognise the vast range of sites and spaces in which multiple practices of transitional justice 'works', through the initiatives of both elites and publics. In this context it is important to acknowledge that the past itself (and that ways that it is represented and memorialised) is fluid, multi-faceted and contested. While states are active players in the commemoration of the Communist past and in broader efforts to shape public memory they do not have a monopoly on the process. Instead, there are a range of other organisations and individuals involved in such commemoration, and consequently there is a diverse range of monuments, memorials and museums dedicated to the abuses and victims of Communist regimes. These are sites where individual and personal negotiations of transitional justice occur, alongside the official memorials, ceremonies and rituals sponsored by the state.

Another key issue is the reach of these spaces of transitional justice. While processes such as lustration and even restitution have a symbolic dimension - showing that post-Communist states are acting to address past injustices - in societal terms their impact may be relatively limited. Not everyone in society was able to reclaim property or necessarily had a personal connection to key figures who were placed on trial. Hence, such practices arguably may have a limited impact on the everyday lives and practices of the majority of the population. 
However, monuments and commemorative landscapes have the potential to reach far more people in the course of their daily lives, and to address their wish for justice in a much more immediate and visible way. For most people, commemoration in the public arena is a form of public recognition that is important in coming to terms with past injustices.

Furthermore, there are important temporal aspects to transitional justice that should be considered. The largest waves of restitution have been completed and there is probably considerably less scope for lustration (since those who could be tried either already have been, or are too old, or have died). Memorialisation in the public arena has a potentially much longer impact with the possibility of shaping public memory across generations. Twenty five years have now elapsed since 1989 and perhaps the forms of transitional justice projects must reflect this. Shaping public memory through commemorative landscapes may well assume a greater importance as other processes decrease in frequency and effectiveness. If the purpose of such memorialisation is to help society to move on (yet without forgetting) then public commemorative landscapes perhaps hold the key. The construction of memorial landscapes may follow on from other, more contentious, processes of transitional justice (which, in turn, may shape the nature of commemorative practices). If such commemoration becomes a more long-term form of transitional justice which persists in public space for decades to come then it will require careful consideration and management.

The final lesson from our chapter that follows on from the points above is that there is a need to explore public reception of landscapes and memorialisation. This is the area in which the literature is most weakly developed. As Barsalou and Baxter suggest, "the impact of all transitional justice processes - memorialisation among them - remains under-researched., 60 They note the difficulty in determining what memorialisation actually contributes to 
reconciliation and justice. Thus we need to explore questions such as how do people relate to memorials and landscapes linked to transitional justice projects in their everyday lives? Do memorials work effectively as vehicles of transitional justice? Are they sites of remembrance or contestation, or do they simply become a backdrop to the everyday use of space in the city? Are they even regarded with apathy or simply ignored? Again, these issues have temporal and generational dimensions and will vary across multiple publics and elites. For example, some authors are sceptical about the long-term impact of museums on the public consciousness. ${ }^{61}$ Furthermore, as Clark suggests, there is a danger that too much memorialisation may inhibit societies' ability to move on. ${ }^{62}$ Moreover, different generations may have very different responses to the ways in which commemorative landscapes function as part of transitional justice, responses shaped by interactions between the generations mediated through the family and representations of history. An important issue for further research is the public reception of memorialisation aimed at righting the wrongs of the Communist era in order to help support the longer-term achievement of transitional justice and its expression in public space.

\footnotetext{
${ }^{1}$ Janine N. Clark, "Reconciliation through remembrance? War memorials and the victims of Vukovar," The International Journal of Transitional Justice 7, no. 1 (2013): 117.
} 
${ }^{2}$ Brendon Hamber, Liz Ševčenko and Ereshnee Naidu, "Utopian dreams or practical possibilities? The challenges of evaluating the impact of memorialization in societies in transition," The International Journal of Transitional Justice 4, no. 3 (2010): 397.

${ }^{3}$ John Bodnar, Remaking America: Public Memory, Commemoration, and Patriotism in the Twentieth Century (Princeton: Princeton University Press, 1992): 15.

${ }^{4}$ Kenneth, E. Foote and Maoz Azaryahu, "Towards a geography of memory: Geographical dimensions of public memory and commemoration," Journal of Political and Military Sociology 35, no. 1 (2007): 127.

5 John R. Gillis, "Memory and identity: The history of a relationship," in Commemorations: The Politics of National Identity, ed. John R. Gillis (Princeton: Princeton University Press, 1994), 24; Cristiane Wilke, "Remembering complexity? Memorials for Nazi victims in Berlin," The International Journal of Transitional Justice 7, no. 1 (2013): 141.

${ }^{6}$ Benedict Anderson, Imagined Communities: Reflections on the Origin and Spread of Nationalism (Revised edition) (London: Verso, 2006).

${ }^{7}$ Benjamin Forest, Juliet Johnson and Karen Till, "Post-totalitarian national identity: public memory in Germany and Russia," Social and Cultural Geography 5, no. 3 (2004): 358, 362.

${ }^{8}$ Karen Till, "Staging the past: landscape designs, cultural identity and Erinnerungspolitik at Berlin's Neue Wache," Ecumene 6, no. 3 (1999): 254.

9 John Bodnar, "Public memory in an American city: Commemoration in Cleveland" in Commemorations: The Politics of National Identity, ed. John R. Gillis (Princeton: Princeton University Press, 1994), 75.

${ }^{10}$ Forest, Johnson and Till, "Post-totalitarian," 358.

${ }^{11}$ Derek H. Alderman, "Memory and place: Geographies of a critical relationship," Social and Cultural Geographies 5, no.3 (2004): 347-355; Nuala Johnson, "Public memory" in A Companion to Cultural Geography, ed. James S. Duncan, Nuala C. Johnson and Richard H. Schein (Oxford: Blackwell, 2004), 316-327; Karen Till, The New Berlin: Memory, Politics, Place (Minneapolis: University of Minnesota Press, 2005).

${ }^{12}$ James Bell, "Redefining national identity in Uzbekistan: Symbolic tensions in Tashkent's official public landscape," Ecumene 6, no. 2 (1999): 186.

${ }^{13}$ Tim Edensor, "National identity and the politics of memory: Remembering Bruce and Wallace in symbolic space," Environment and Planning D 15, no. 2 (1997): 178.

${ }^{14}$ Gail Kligman and Katherine Verdery, Peasants Under Siege: The Collectivization of Romanian Agriculture, 1949-1962 (Princeton: Princeton University Press, 2011), 9.

${ }^{15}$ Katherine Verdery, What Was Socialism and What Comes Next? (Princeton: Princeton University Press, 1996), 136.

${ }^{16}$ Katherine Verdery, The Political Lives of Dead Bodies: Reburial and Postsocialist Change (New York: Columbia University Press, 1999), 116, 124.

${ }^{17}$ Forest, Johnson, and Till, "Post-totalitarian," 358-363.

${ }^{18}$ Hamber, Ševčenko, and Naidu, "Utopian dreams," 398.

${ }^{19}$ Judy Barsalou and Victoria Baxter, The Urge to Remember: The Role of Memorials in Social Reconstruction and Transitional Justice.(Washington DC: United States Institute of Peace, 2007), 4. Accessed from http://www.usip.org/publications/the-urge-remember-therole-of-memorials-in-social-reconstruction-and-transitional on 3 October 2013.

${ }^{20}$ Benjamin Forest and Juliet Johnson, "Unravelling the threads of history: Soviet-era monuments and Post-Soviet national identity in Moscow," Annals of the Association of American Geographers 92, no. 3 (2002): 271.

${ }^{21}$ David Crowley and Susan E. Reid, "Socialist spaces: Sites of everyday life in the Eastern bloc" in Socialist Spaces: Sites of Everyday Life in the Eastern Bloc, ed. David Crowley and Susan E. Reid (Oxford: Berg, 2002), 11. 
${ }^{22}$ Gordon Church, "Bucharest: Revolution in the townscape art" in The Socialist City: Spatial Structure and Urban Policy, ed. R.A. French and F.E.I. Hamilton (Chichester: Wiley, 1979), 502-3; Robert Argenbright, "Remaking Moscow: New places, new selves," The Geographical Review 89, no. 1 (1999): 6.

${ }^{23}$ Marius Czepczyński, Cultural Landscapes of Post-Socialist Cities: Representations of Powers and Needs (Aldershot: Ashgate, 2008), 116-125.

${ }^{24}$ Deborah Schultz and Alina Serban, "Public memory and national identity under construction: The trajectory of monuments in Romania in the Communist and PostCommunist periods," Centropa 10, no. 1 (2010): 64.

${ }^{25}$ Czepczyński, Cultural Landscapes, 115.

${ }^{26}$ Schultz and Serban, "Public memory," 63.

${ }^{27}$ Kenneth E. Foote, Atilla Tóth and Annet Árvay, "Hungary after 1989: Inscribing a new past on place," Geographical Review 90, no. 3 (2000): 310-311.

${ }^{28}$ Maria Todorova, "The mausoleum of Georgi Dimitrov as lieu de mémoire," Journal of Modern History 78, (June 2006): 388.

${ }^{29}$ Beverly James, "Fencing in the past: Budapest's Statue Park museum," Media, Culture and Society 21, no. 3 (1999): 303.

${ }^{30}$ Marko Lehti, Matti Jutila and Markku Jokisipilä, "Never-Ending Second World War: Public Performances of National Dignity and the Drama of the Bronze Soldier," Journal of Baltic Studies 39, no. 4 (2008): 393-418.

${ }^{31}$ Reuban Rose-Redwood, Derek Alderman and Maoz Azaryahu, "Geographies of toponymic inscription: New directions in critical place-name studies," Progress in Human Geography 34, no. 4 (2010): 460.

${ }^{32}$ Maoz Azaryahu, "The power of commemorative street names," Environment and Planning D: Society and Space 14, no. 3 (1996): 318.

${ }^{33}$ Duncan Light, "Street names in Bucharest, 1990-1997: exploring the modern historical geographies of post-socialist change," Journal of Historical Geography 30, no. 1 (2004): 160. ${ }^{34}$ Zbynek Z. Stransky, "Museums in post-communist countries," in Museums and Europe 1992, ed. Susan Pearce (London: Athlone Press, 1992): 174-6.

${ }^{35}$ Simina Bădica, "The black hole paradigm: Exhibiting communism in post-communist Romania," in History of Communism in Europe: Volume 1 Politics of Memory in PostCommunist Europe, (Bucharest: Zeta Books, 2010), 88-89.

${ }^{36}$ Bădica, "Black hole".

${ }^{37}$ Light, "Street names," 163-164.

${ }^{38}$ Elizabeth Jelin, "Public memorialization in perspective: Truth, justice and the memory of past repression in the Southern cone of South America," The International Journal of Transitional Justice 1, no. 1 (2007): 147.

${ }^{39}$ See Czepczyński, Cultural Landscapes, 138 in the case of Poland.

${ }^{40}$ See Forest and Johnson, "Unravelling the threads," 270.

${ }^{41}$ See, for example: Lavinia Stan, "Reckoning with the Communist past in Romania: A scorecard.", Europe-Asia Studies 65, no.1 (2013): 142.

${ }^{42}$ Susan, C. Pearce, "Delete, restart or rewind? Post-1989 public memory work in EastCentral Europe.", Sociology Compass 5, no. 4 (2011): 256-7.

${ }^{43}$ Tim Edensor, National Identity, Popular Culture and Everyday Life (Oxford: Berg, 2002), 85.

${ }^{44}$ Donald Horne, The Great Museum: The Re-presentation of History (London: Pluto, 1984), 165-179; Fiona McLean, "Museums and the construction of national identity: A review," International Journal of Heritage Studies 3, no. 1(1998): 244-252.

45 Jelin, "Public memorialization," 141. 
${ }^{46}$ Barsalou and Baxter, Urge to Remember, 14.

${ }^{47}$ Liz Sevcenko, cited in Barsalou and Baxter, Urge to Remember, 14.

${ }^{48}$ Michael C. Hall, Tourism and Politics: Policy, Power and Place (Chichester: Wiley, 1994); Nigel Morgan and Annette Pritchard, Tourism, Promotion and Power: Creating Images, Creating Identities (Chichester: Wiley, 1998); Michael C. Hall, Tourism: Rethinking the Social Science of Mobility (London: Routledge, 2005).

${ }^{49}$ Catherine Palmer, "An ethnography of Englishness: Experiencing identity through tourism," Annals of Tourism Research 32, no. 1 (2005): 11.

${ }^{50}$ Michael Billig, Banal Nationalism (London: Sage, 1995).

${ }^{51}$ Morgan and Pritchard, Tourism Promotion; Derek Hall, "Destination branding, niche marketing and national image projection in Central and Eastern Europe," Journal of Vacation Marketing 5, no. 3 (1999): 227-237; Derek Hall, "Brand development, tourism and national identity: the re-imaging of former Yugoslavia," Brand Management 9, no.4-5 (2001): 323 334; Duncan Light, "Romania: national identity, tourism promotion and European integration," in Tourism in the New Europe: The Challenges and Opportunities of EU

Enlargement, ed. Derek Hall, Melanie Smith and Barbara Marciszewska (Wallingford: CABI, 2006), 256-269.

${ }^{52}$ Duncan Light, "Heritage as informal education," in Heritage, Tourism and Society, ed. David T. Herbert (London: Mansell, 1995): 117-145.

${ }_{53} \mathrm{http}: / /$ okupacijasmuzejs.lv/en/about-museum/mission-and-history accessed 18 October.

${ }^{54}$ Bădica, "Black hole," 96-101; http://www.memorialsighet.ro/, accessed 18 October 2013.

${ }^{55} \mathrm{http} / / /$ en.stiftung-hsh.de/document.php?cat_id=CAT_231\&special=0, accessed 19 October 2013.

${ }^{56} \mathrm{http}: / / \mathrm{www}$. terrorhaza.hu/, accessed 19 October 2013.

${ }^{57}$ Joy Sather-Wagstaff, Heritage that Hurts: Tourists in the Memoryscapes of September 11 (Walnut Creek: Left Coast Press, 2011), 77.

${ }^{58}$ See, for example, Sather-Wagstaff, Heritage, 115-170; Laurajane Smith, "The cultural 'work' of tourism," in The Cultural Moment in Tourism, ed. Laurajane Smith, Emma

Waterton and Steve Watson (London: Routledge, 2012), 219-229; Andrea Witcombe, "Using immersive and interactive approaches to interpreting traumatic experiences for tourists," in Heritage and Tourism: Place, Encounter, Engagement, ed. Russell Staiff, Robyn Bushell and Steve Watson (London: Routledge, 2013), 152-170.

${ }^{59}$ Hamber, Ševčenko and Naidu, "Utopian dreams", 145-148.

${ }^{60}$ Barsalou and Baxter, Urge to Remember, 3.

${ }^{61}$ Hamber, Ševčenko, and Naidu, "Utopian dreams" 415-418.

${ }^{62}$ Clark, "Reconciliation through remembrance?", 133-134. 